\title{
Comparative study for the defluoridation of water by Coagulation
}

\author{
Djamel Atia, Abdelghani Hoggui, D. Bebba Ahmed Abdelhafid* \\ Laboratoire de Valorisation et Technologie des Ressources Sahariennes, \\ Département Sciences de la Matière, Institut des Sciences et Technologie Centre, \\ Universitaire Ouargla, Algérie \\ *E-mail address: Atia.sahan1@gmail.com
}

\begin{abstract}
El-Oued is known for some diseases caused by fluoride concentration in drinkable water. To reduce it, we have chosen a sample with the highest content of fluoride among many sources in order to coagulate it with $\mathrm{Al}_{2}\left(\mathrm{SO}_{4}\right)_{3} \cdot 18 \mathrm{H}_{2} \mathrm{O}, \mathrm{Fe}_{2}\left(\mathrm{SO}_{4}\right)_{3} \cdot \mathrm{H}_{2} \mathrm{O}$ and $\mathrm{FeSO}_{4}$. In order to get better reduction yield of fluoride, a study has been done on the influencing parameters (concentration, $\mathrm{pH}$, temperature) to choose the best conditions. The remove of fluoride is favorable at low concentration of $\mathrm{Al}_{2}\left(\mathrm{SO}_{4}\right)_{3}$, at room temperature and normal acidity.
\end{abstract}

Keywords: fluorine; defluoridation; drinkable water; coagulation

\section{INTRODUCTION}

The concentration of fluoride in groundwater depends on the geological characteristics, and chemical properties of rocks and climate of the region. Fluoride content in the groundwater of northern Algerian desert often exceeds the world Health Organization standards, which indicated that the consumption of high fluoride water for long periods causes health complications from discolored teeth to fluoride poisoning bone. When concentration between $(0.5-1.5 \mathrm{mg} / 1)$, it gives good protection against tooth decay, and if it exceeds $1.5 \mathrm{mg}$ $/ 1$, defect occurs in teeth enamel but at a concentration between 4 and $8 \mathrm{mg} / 1$, it leads to the risk of fluorosis skeletal [1].

The water of El Oued is characterized by high concentrations of fluoride, associated with severely high and excessive total mineralization. This water is the only source of drinking. The hot and dry climate has forced people to consume a lot of water which leads to raise the daily consumption rate of fluoride, in addition the large consumption of dates and tea leads to the spread of fluorosis disease which is characterized by the yellowish of tooth enamel according to the classification of the national program of school health $[2,3]$. To prevent these diseases from happening or reduce them, many defluoridation techniques are used such as: membrane technologies, precipitation and adsorption. A comparative study of coagulation has been done with different sulfate salts of (Aluminum, iron (II) and iron (III) ) then determination of optimal conditions of factors affecting the reduction of fluoride in drinking water. 


\section{EXPERIMENTAL SECTION}

\section{1. Preparation of curve witness fluoride}

To determine the concentration of fluoride in Various samples, a potentiometer method was used (Rodier2005) [4]. Different standard concentration solutions were prepared from $\mathrm{NaF}$ salt in cups of plastic. Then their potential are measured by using specific fluoride pole (ISE15381/1) and a pH-meter model (pH211), using a solution of TISAB ${ }^{(\mathbf{9})}$. The graph $\mathrm{E}=\mathrm{f}$ $\left(\log C_{F}\right)$ is presented in Figure 1.

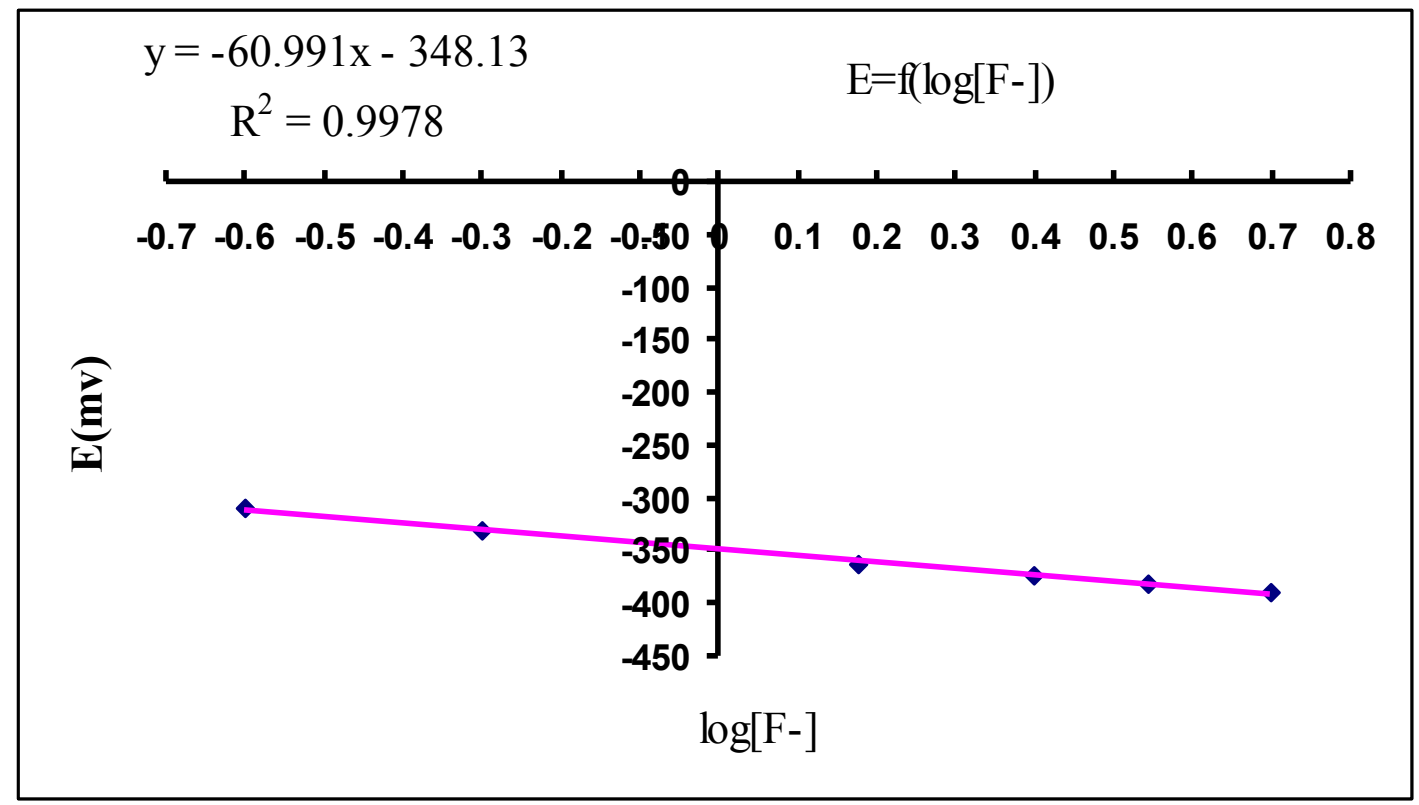

Figure1. The witness graph for fluoride.

\section{2. Determination of fluoride concentration in some samples of the study area}

The concentration of fluoride has been determined in some water sources of the study area in order to determine and treat the largest content of fluoride. The results are presented in Table 1. The selected sample (cold water of Shuhada) has a concentration of fluoride $2.61 \mathrm{mg}$ $/ 1$.

Table1. Fluoride concentration for some water in the study areas at $\mathrm{T}=19.3{ }^{\circ} \mathrm{C}$.

\begin{tabular}{|c|c|c|c|c|c|c|c|}
\hline Sources of water & mars city & $\begin{array}{c}\text { mastur } \\
\text { city }\end{array}$ & 400 city & $\begin{array}{c}8 \text { may } \\
\text { city }\end{array}$ & $\begin{array}{c}1 \text { Nov } \\
\text { City }\end{array}$ & $\begin{array}{c}\text { Nezla } \\
\text { city }\end{array}$ & Shuhada \\
\hline$\left[\mathbf{F}^{-}\right] \mathbf{~ ( m g / l )}$ & 1.87 & 1.90 & 1.92 & 1.84 & 1.94 & 0.46 & 2.61 \\
\hline
\end{tabular}

\section{3. Determination of the predominant concentration of ions in the studied water}

The study was done according to (Rodier2005) [4] on cold water of Shuhada as follows: 


\section{3. 1. Nitrates and sulfates}

Spectroscopy method (UV) ray using (spectrophotometer DR 2400).

\section{3. 2. Total hardness} $\mathrm{pH}=10$.

By complexity with EDTA ${ }^{(\mathbf{1})}$ in the presence of Eriochrome BlackT at buffer solution of

\subsection{Sodium and potassium}

Using flame atomic absorption analysis.

\section{3. 4. Alkalinity}

Determining $\mathrm{TA}^{(7)}$ and $\mathrm{TAC}^{(\mathbf{8})}$ using $\mathrm{PhPh}^{(\mathbf{6})}$ and $\mathrm{MO}^{(5)}$ indicators respectively.

\section{3. 5. Chlorides}

Volumetric method for Mohr.

\section{3. 6. Calcium concentration}

By complexity with $\operatorname{EDTA}^{(\mathbf{1})}$ in the presence of murexide at a solution of $\mathrm{pH}=12$.

\section{3. 7. Magnesium concentration}

Calculated from the difference Total hardness and Calcium concentration. The results are presented in Table 2 .

Table 2. Physico-chemestry properties of Shuhada water.

\begin{tabular}{|l|l|l|l|l|l|l|l|l|l|}
\hline Property & $\mathrm{SO}_{4}^{2-}$ & $\mathrm{Ca}^{2+}$ & $\mathrm{Mg}^{2+}$ & $\mathrm{Na}^{+}$ & $\mathrm{K}^{+}$ & $\mathrm{NO}_{3}^{-}$ & $\mathrm{TA}$ & $\mathrm{TAC}$ & $\mathrm{Cl}^{-}$ \\
\hline $\mathbf{C ~ ( m g / l )}$ & 544 & 492 & 140 & 55 & 2.4 & 5.9 & 0 & 105 & 402 \\
\hline
\end{tabular}

\section{4. Treatment}

The factors affecting (mass, $\mathrm{pH}$, and temperature $\mathrm{T}$ ) were studied by the Coagulation method using $\mathrm{Al}_{2}\left(\mathrm{SO}_{4}\right)_{3} \cdot 18 \mathrm{H}_{2} \mathrm{O}, \mathrm{Fe}_{2}\left(\mathrm{SO}_{4}\right)_{3} \cdot \mathrm{H}_{2} \mathrm{O}$ and $\mathrm{FeSO}_{4}$ at a purity of $(98-100) \%, 100 \%$ and $84 \%$ respectively.

\section{4. 1. Effect of cathion concentration}

Based on the adsorption of $\mathrm{F}^{-}$on both $\mathrm{Al}(\mathrm{OH})_{3}$ and $\mathrm{Fe}(\mathrm{OH})_{3}$ according to equilibriums (1), (2), (3) and (4) [8-10]. $100 \mathrm{ml}$ of Shuhada water was put in each cup of plastic then the $\mathrm{pH}$ and temperature $\mathrm{T}$ were measured, after that different amount of the same salt was added to each cup. After stirring for three minutes, they are left for a while then filtered, finally the amount of fluoride in the filtrate was measured.

The results were presented in Table 3 . 
Table 3. Relation between the added cation and the residual fluoride.

\begin{tabular}{|c|c|c|c|}
\hline$\left[\mathbf{M}^{\mathrm{n}+}\right](\mathrm{g} / \mathrm{l})$ & {$\left[\mathrm{F}^{-}\right]\left(\mathrm{Al}^{3+}\right)^{(2)}(\mathrm{mg} / \mathrm{l})$} & {$\left[\mathrm{F}^{-}\right]\left(\mathrm{Fe}^{3+}\right)^{(3)}(\mathrm{mg} / \mathrm{l})$} & {$\left[\mathrm{F}^{-}\right]\left(\mathrm{Fe}^{2+}\right)^{(4)}(\mathrm{mg} / \mathrm{l})$} \\
\hline 0.0020 & 1.79 & & \\
\hline 0.0024 & 1.57 & & \\
\hline 0.0028 & 1.41 & & \\
\hline 0.0032 & 1.28 & & \\
\hline 0.0040 & 1.09 & & \\
\hline 0.0048 & 0.96 & & \\
\hline 0.01 & & 2.48 & \\
\hline 0.03 & & 2.08 & \\
\hline 0.05 & & 1.67 & \\
\hline 0.06 & & & 1.63 \\
\hline 0.08 & & 1.49 & \\
\hline 0.11 & & 1.25 & \\
\hline .0 .13 & & 1.2 & \\
\hline 0.31 & & & 1.61 \\
\hline 1.55 & & & 1.57 \\
\hline 3.10 & & & 1.63 \\
\hline 6.19 & & & 1.97 \\
\hline
\end{tabular}

\section{4. 2. Effect of $\mathrm{pH}$}

Based on the adsorption of fluoride ion on cation hydroxides $\left[\mathrm{Al}(\mathrm{OH})_{3}\right.$ and $\left.\mathrm{Fe}(\mathrm{OH})_{3}\right]$ which is related to the $\mathrm{pH}$ of the studied water according to equilibriums (5) and (6) for $\mathrm{Al}^{3+}$ [8], equilibriums (7) and (8) for $\mathrm{Fe}^{3+}$ [9] and equilibrium (9) for $\mathrm{Fe}^{2+}[10]$.

We repeat the same steps of the previous experiment as mentioned in (2.4.1) by fixing the temperature and the added optimal concentration of each cation separately but changing the $\mathrm{pH}$ by buffer solutions. The results are presented in Table 4 and Figure 2 . 
Table 4. Relation between the $\mathrm{pH}$ and the residual fluoride.

$\left[\mathrm{Al}^{3+}\right]=0.0024 \mathrm{~g} / \mathrm{l},\left[\mathrm{Fe}^{3+}\right]=0.08 \mathrm{~g} / \mathrm{l},\left[\mathrm{Fe}^{2+}\right]=1.55 \mathrm{~g} / \mathrm{l}$

\begin{tabular}{|c|c|c|c|}
\hline $\mathbf{p H}$ & {$\left[\mathbf{F}^{-}\right]\left(\mathbf{A l}^{\mathbf{3 +}}\right)^{(\mathbf{2})}(\mathbf{m g} / \mathbf{l})$} & {$\left[\mathbf{F}^{-}\right]\left(\mathbf{F e}^{\mathbf{3 +}}\right)^{\mathbf{3})}(\mathbf{m g} / \mathbf{l})$} & {$\left[\mathbf{F}^{-}\right]\left(\mathbf{F e}^{\mathbf{2 +}}\right)^{(\mathbf{4})}(\mathbf{m g} \mathbf{l} \mathbf{)}$} \\
\hline 4 & & & 2.61 \\
\hline 4.02 & 1.8 & & \\
\hline 4.3 & & 1.64 & \\
\hline 5 & & 1.36 & 2.2 \\
\hline 5.07 & 1.46 & & \\
\hline 6 & 1.23 & 1.26 & 2.06 \\
\hline 7 & & & 1.66 \\
\hline 7.02 & 1.27 & & \\
\hline 7.4 & & 1.35 & 1.49 \\
\hline 7.5 & & & 1.45 \\
\hline 8 & 1.5 & & \\
\hline 8.1 & & 1.66 & \\
\hline
\end{tabular}

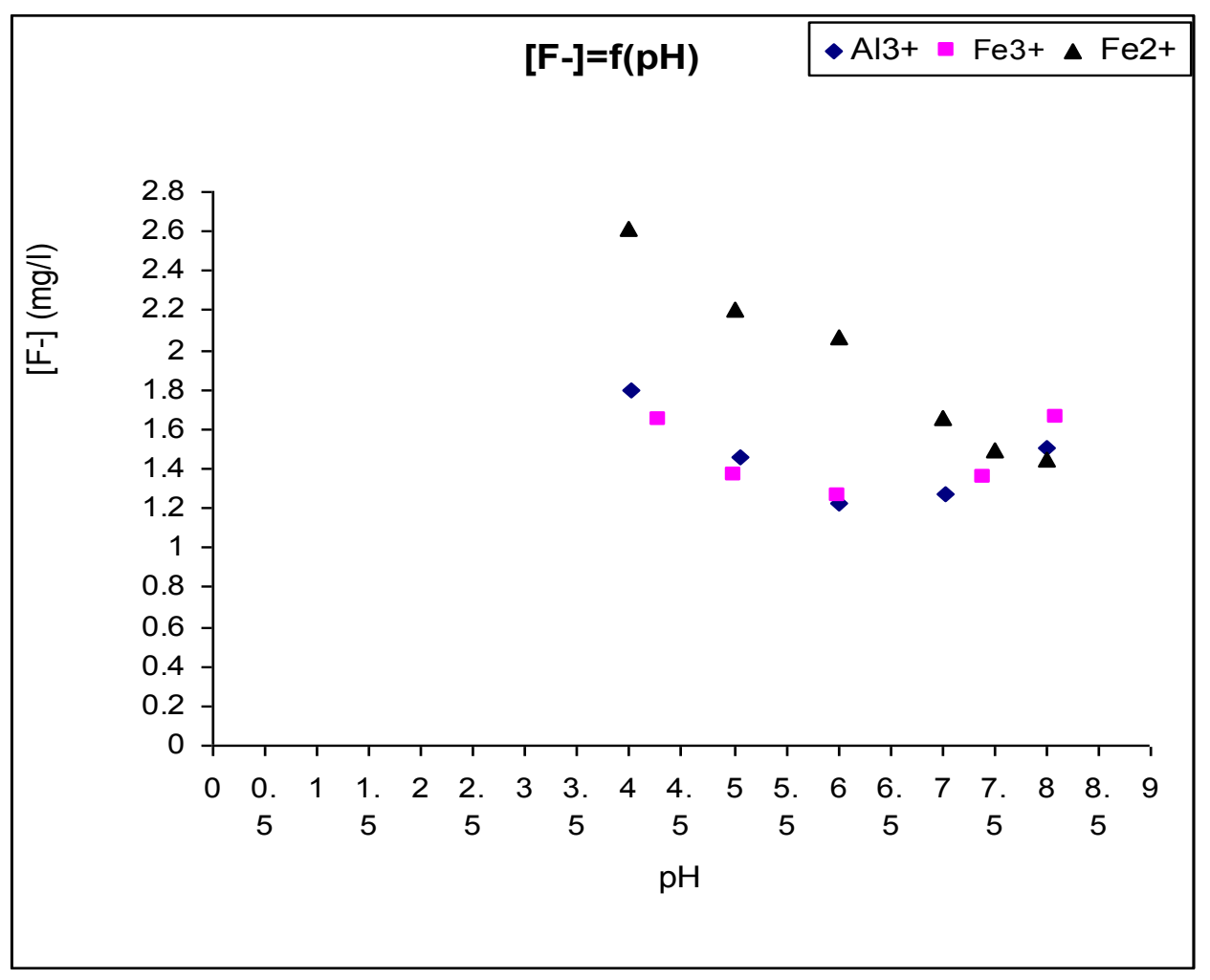

Figure 2. variation of residual fluoride against $\mathrm{pH}$. 


\section{4. 3. Effect of temperature $T$}

The same steps of the experiment are repeated as mentioned in (2.4.2) by fixing the concerned added salt and the optimal $\mathrm{pH}$, but changing the temperature. The results were presented in Table 5 and Figure 3 [5].

Table 5. Relation between the temperature and the residual fluoride.

\begin{tabular}{|c|c|c|c|}
\hline $\mathbf{T}\left({ }^{\circ} \mathrm{C}\right)$ & {$\left[\mathrm{F}^{-}\right]\left(\mathrm{Al}^{3+}\right)^{(2)}(\mathrm{mg} / \mathrm{l})$} & {$\left[\mathrm{F}^{-}\right]\left(\mathrm{Fe}^{3+}\right)^{(3)}(\mathrm{mg} / \mathrm{l})$} & {$\left[\mathrm{F}^{-}\right]\left(\mathrm{Fe}^{2+}\right)^{(4)}(\mathrm{mg} / \mathrm{l})$} \\
\hline 16.4 & & & 1.41 \\
\hline 17 & & 2 & \\
\hline 20 & 1.67 & & \\
\hline 25 & & & 1.15 \\
\hline 25.4 & & 1.62 & \\
\hline 26.5 & 1.5 & & \\
\hline 30 & 1.41 & & 1.02 \\
\hline 35 & & & 0.83 \\
\hline 35.2 & & 1.05 & \\
\hline 40 & 1.21 & & 0.69 \\
\hline 45 & 1.1 & 0.73 & 0.56 \\
\hline
\end{tabular}

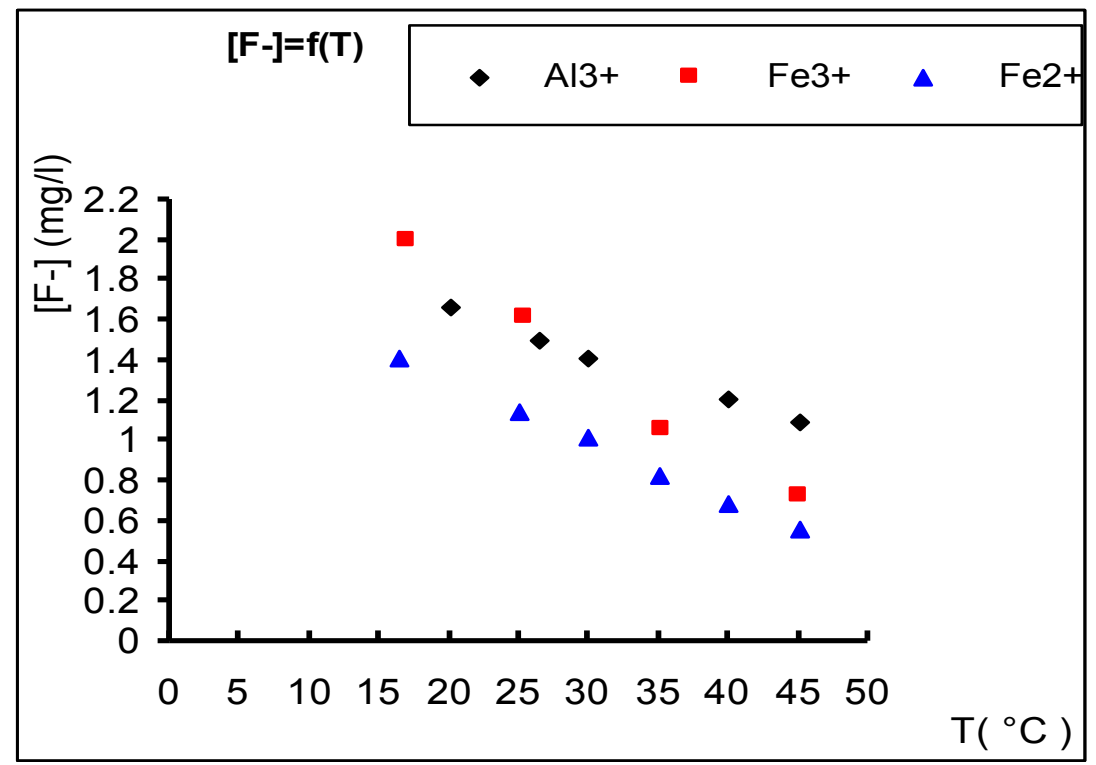

Figure 3. Variation of residual fluoride against temperature. 


\section{5. Equations and equilibriums}

$$
\begin{aligned}
& 6 \mathrm{HCO}_{3}{ }^{-}+\mathrm{Al}_{2}\left(\mathrm{SO}_{4}\right)_{3} \rightleftharpoons 3 \mathrm{SO}_{4}{ }^{2-}+2 \mathrm{Al}(\mathrm{OH})_{3(\mathrm{~S})}+6 \mathrm{CO}_{2} \ldots . .(1) \\
& \mathrm{Fe}^{3+}+3 \mathrm{OH}^{-} \leftrightharpoons \mathrm{Fe}(\mathrm{OH})_{3(\mathrm{~S})} \ldots . .(2) \\
& \mathrm{Fe}^{2+}+2 \mathrm{HCO}_{3}^{-} \leftrightharpoons \mathrm{Fe}\left(\mathrm{HCO}_{3}\right)_{2(\mathrm{~S})} \ldots \ldots(3) \\
& 4 \mathrm{Fe}\left(\mathrm{HCO}_{3}\right)_{2}+10 \mathrm{H}_{2} \mathrm{O}+\mathrm{O}_{2} \rightleftharpoons 4 \mathrm{Fe}(\mathrm{OH})_{3(\mathrm{~S})}+8 \mathrm{H}_{2} \mathrm{CO}_{3} . . \text { (4) } \\
& \mathrm{Al}(\mathrm{OH})_{3(\mathrm{~S})}+3 \mathrm{H}_{3} \mathrm{O}^{+} \rightleftharpoons \mathrm{Al}^{3+}+6 \mathrm{H}_{2} \mathrm{O} \\
& \mathrm{Al}(\mathrm{OH})_{3(\mathrm{~S})}+\mathrm{OH}^{-} \rightleftharpoons \mathrm{Al}(\mathrm{OH})_{4}{ }^{-} \\
& \mathrm{Fe}(\mathrm{OH})_{3(\mathrm{~S})}+3 \mathrm{H}_{3} \mathrm{O}^{+} \rightleftharpoons \mathrm{Fe}^{3+}+6 \mathrm{H}_{2} \mathrm{O} \\
& \mathrm{Fe}(\mathrm{OH})_{3(\mathrm{~S})}+\mathrm{OH}^{-} \rightleftharpoons \mathrm{Fe}(\mathrm{OH})_{4}{ }^{-} \\
& \mathrm{Fe}^{3+}+3 \mathrm{OH}^{-} \rightleftharpoons \mathrm{Fe}(\mathrm{OH})_{3(S)} \\
& \eta=A e^{B / T} \\
& \mathbf{V}=\frac{\text { Z.D.E }}{4 \pi \eta} \\
& \mathbf{V}_{\text {mob }}=\mathbf{V} / \mathbf{E}
\end{aligned}
$$

\section{RESULTS AND DISCUSSION}

According to the results of table 2 we observe that the high concentrations of $\left(\mathrm{Ca}^{2+}, \mathrm{Mg}^{2+}, \mathrm{SO}_{4}{ }^{2-}, \mathrm{Cl}^{-}\right)$exceed the $\mathrm{WHO}^{(10)}$ standards of water. This related to the geological characteristics and the structure of rocks .

$\checkmark$ According to the results of Table 3, defluoridation by the use of $\mathrm{Al}_{2}\left(\mathrm{SO}_{4}\right)_{3}$ is the best. This can be explained by the adsorption of fluoride on the flocks of $\mathrm{Al}(\mathrm{OH})_{3}$ (equilibrium 1). The optimal concentrations of cations resulting from both $\mathrm{Al}_{2}\left(\mathrm{SO}_{4}\right)_{3} \cdot 18 \mathrm{H}_{2} \mathrm{O}, \mathrm{Fe}_{2}\left(\mathrm{SO}_{4}\right)_{3} \cdot \mathrm{H}_{2} \mathrm{O}$ and $\mathrm{FeSO}_{4}$ are $0.0024 \mathrm{~g} / 1,0.08 \mathrm{~g} / 1$ and $1.55 \mathrm{~g} / 1$ respectively.

$\checkmark$ According to the results of table 4 , the optimal $\mathrm{pH}$ resulting by the addition of both $\mathrm{Al}_{2}\left(\mathrm{SO}_{4}\right)_{3} \cdot 18 \mathrm{H}_{2} \mathrm{O}, \mathrm{Fe}_{2}\left(\mathrm{SO}_{4}\right)_{3} \cdot \mathrm{H}_{2} \mathrm{O}$ and $\mathrm{FeSO}_{4}$ are 8.0, 7.6 and 7.5 respectively.

$\checkmark$ According to the results of Table 5 we observe that residual $\left[\mathrm{F}^{-}\right]$is decreased when $\mathrm{T}$ is increased, this can be proved by the following: Increasing $\mathrm{T}$ leads to the decrease of [equation of Guzman-andrad] (1), so V is increased [equation (2)]. As a result $\mathrm{V}$ mob is increased [equation (3)] [6, 7]. The optimal temperatures resulting from both $\mathrm{Al}_{2}\left(\mathrm{SO}_{4}\right)_{3} \cdot 18 \mathrm{H}_{2} \mathrm{O}, \mathrm{Fe}_{2}\left(\mathrm{SO}_{4}\right)_{3} \cdot \mathrm{H}_{2} \mathrm{O}$ and $\mathrm{FeSO}_{4}$ are $26.5^{\circ} \mathrm{C}, 25.4{ }^{\circ} \mathrm{C}$ and $16.4{ }^{\circ} \mathrm{C}$ respectively. 


\section{CONCLUSION}

- According to this study on the water of some region of El-Oued, it appear that most of them Contain a high quantity of fluoride exceeds the standard value of (WHO) ${ }^{(10)}$ with a high total hardness.

- The present investigation indicates that reducing fluoride from water by using $\mathrm{Al}_{2}\left(\mathrm{SO}_{4}\right)_{3}$ is economic and less harmful for health.

- Through the study of factors affecting (concentration, $\mathrm{pH}$, temperature) it is possible to choose the best conditions for a reduction process with $\mathrm{Al}_{2}\left(\mathrm{SO}_{4}\right)_{3}$ by adding an amount at a concentration of $0.0024 \mathrm{~g} / 1, \mathrm{pH}=8$ and a temperature of $26.5^{\circ} \mathrm{C}$.

\section{ABBREVIATIONS}

EDTA $^{(1)}$ : ComplexonIII (Ethylene diamine tetra acetic acid disodium salt).

$\left[\mathrm{F}^{-}\right] \mathrm{Al}^{3+(2)}$ : concentration of fluoride residual after adding $\mathrm{Al}_{2}\left(\mathrm{SO}_{4}\right)_{3}$ to water.

$\left[\mathrm{F}^{-}\right] \mathrm{Fe}^{3+(3)}$ : concentration of fluoride residual after adding $\mathrm{Fe}_{2}\left(\mathrm{SO}_{4}\right)_{3}$ to water.

$\left[\mathrm{F}^{-}\right] \mathrm{Fe}^{2+(4)}$ : concentration of fluoride residual after adding $\mathrm{FeSO}_{4}$ to water.

$\mathrm{MO}^{(5)}$ : methyl orange

$\mathrm{Ph} . \mathrm{Ph}^{(6)}$ : $\quad$ phenolphthalein

$\mathrm{TA}^{(7)}$ : $\quad$ alkalimetric title.

$\mathrm{TAC}^{(8)}$ : $\quad$ The complete alkalimetric title.

TISAB $^{(9)}$ : $\quad$ total ionic strength adjustment buffer

$\mathrm{WHO}^{(10)}$ : World Health Organization.

\section{References}

[1] WHO, Fluoride in drinking water, IWA Publishing, London, 2006.

[2] Programme National de Santé Bucco-Dentaire en Milieu Scolaire, Ministčre de la Santé et de la Population, Algérie, Mai 2001.

[3] Circulaire interministérielle du 07 Mai 2001 relative au Programme National de Santé Bucco-Dentaire en Milieu Scolaire, Ministčre de la Santé et de la Population, Ministčre de l'Education Nationale, Algérie.

[4] Jean Rodier et coll., L'analyse de l'eau:eaux naturelles, eaux résiduaires, eau de mer, 8 édition; Paris 2005, pp. 219-221 et 299-310.

[5] Saoud D., Etude de l'effet des dérives organiques sur la formation de lithiase urinaire dans la région du Sud-Est Algérienne. Thèse de Magister, Université de Ouargla 2009, pp. 71.

[6] Brodsky A., Zdenek V., Possibilités de décarbonatation des eaux à la chaux, la technique de l'eau et de l'assainissement, 3 (1971) 33-40.

[7] M. G. Sujana, G. Soma, N. Vasumathi, S. Anand, Journal of Fluorine Chemistry 130(8) (2009) 749-754. 
[8] Djamel Atia, Abdelghani Hoggui, International Letters of Chemistry, Physics and Astronomy 5 (2013) 39-46.

[9] Djamel Atia, Abdelghani Hoggui, International Letters of Chemistry, Physics and Astronomy 5 (2013) 57-65.

[10] Djamel Atia, Abdelghani Hoggui, International Letters of Chemistry, Physics and Astronomy 7(1) (2013) 39-46. 